Article

\title{
The IкB Kinase Inhibitor ACHP Targets the STAT3 Signaling Pathway in Human Non-Small Cell Lung Carcinoma Cells
}

\author{
Jong Hyun Lee ${ }^{1, \dagger}$, Chakrabhavi Dhananjaya Mohan ${ }^{2,+}$, Salundi Basappa ${ }^{3, \dagger}$, \\ Shobith Rangappa ${ }^{4}$, Arunachalam Chinnathambi 5,*, Tahani Awad Alahmadi 5,6, \\ Sulaiman Ali Alharbi ${ }^{5}$, Alan Prem Kumar ${ }^{7,8}$ (D), Gautam Sethi ${ }^{8}$, Kwang Seok Ahn ${ }^{1, *(D)}$ \\ and Kanchugarakoppal S Rangappa ${ }^{9, *}$ \\ 1 College of Korean Medicine, Kyung Hee University, \#47, Kyungheedae-gil, Dongdaemoon-gu, \\ Seoul 130-701, Korea; 88mirue@gmail.com \\ 2 Department of Studies in Molecular Biology, University of Mysore, Manasagangotri, Mysore 570006, India; \\ cd.mohan@yahoo.com \\ 3 Laboratory of Chemical Biology, Department of Studies in Organic Chemistry, University of Mysore, \\ Manasagangotri, Mysore 570006, India; salundibasappa@gmail.com \\ 4 Adichunchanagiri Institute for Molecular Medicine, BG Nagara-571448, Nagamangala Taluk, \\ Mandya District 571448, India; shobithrangappa@gmail.com \\ 5 Department of Botany and Microbiology, College of Science, King Saud University, \\ Riyadh 11451, Saudi Arabia; talahmadi@ksu.edu.sa (T.A.A.); sharbi@ksu.edu.sa (S.A.A.) \\ 6 Department of Pediatrics, College of Medicine and King Khalid University Hospital, King Saud University \\ Medical City, Riyadh 11461, Saudi Arabia \\ 7 Cancer Science Institute of Singapore, National University of Singapore, Singapore 117599, Singapore; \\ csiapk@nus.edu.sg \\ 8 Department of Pharmacology, Yong Loo Lin School of Medicine, National University of Singapore, \\ Singapore 117600, Singapore; phcgs@nus.edu.sg \\ 9 Institution of Excellence, Vijnana Bhavan, University of Mysore, Manasagangotri, Mysore 570006, India \\ * Correspondence: carunachalam@ksu.edu.sa (A.C.); ksahn@khu.ac.kr (K.S.A.); rangappaks@gmail.com or \\ rangappaks@yahoo.com (K.S.R.) \\ + These authors contributed equally to this work.
}

Received: 13 July 2019; Accepted: 13 November 2019; Published: 13 December 2019

check for updates

\begin{abstract}
STAT3 is an oncogenic transcription factor that regulates the expression of genes which are involved in malignant transformation. Aberrant activation of STAT3 has been observed in a wide range of human malignancies and its role in negative prognosis is well-documented. In this report, we performed high-throughput virtual screening in search of STAT3 signaling inhibitors using a cheminformatics platform and identified 2-Amino-6-[2-(Cyclopropylmethoxy)-6-Hydroxyphenyl]-4-Piperidin-4-yl Nicotinonitrile (ACHP) as the inhibitor of the STAT3 signaling pathway. The predicted hit was evaluated in non-small cell lung cancer (NSCLC) cell lines for its STAT3 inhibitory activity. In vitro experiments suggested that ACHP decreased the cell viability and inhibited the phosphorylation of STAT3 on Tyr705 of NSCLC cells. In addition, ACHP imparted inhibitory activity on the constitutive activation of upstream protein tyrosine kinases, including JAK1, JAK2, and Src. ACHP decreased the nuclear translocation of STAT3 and downregulated its DNA binding ability. Apoptosis was evidenced by cleavage of caspase- 3 and PARP with the subsequent decline in antiapoptotic proteins, including Bcl-2, Bcl-xl, and survivin. Overall, we report that ACHP can act as a potent STAT3 signaling inhibitor in NSCLC cell lines.
\end{abstract}

Keywords: ACHP; STAT3 signaling inhibitor; NSCLC; cytotoxicity 


\section{Introduction}

Lung cancer is the second most common type of cancer in both sexes and a leading cause of cancer-related deaths [1-4]. Non-small cell lung cancer (NSCLC) and small cell lung carcinoma are the two major subtypes, which account for about $80-85 \%$ and $10-15 \%$ of all lung cancer, respectively [5-10]. The development and progression of NSCLC are tightly associated with smoking, exposure to asbestos and radon, drinking of arsenic-contaminated water, family history, and inhalation of carcinogens, such as beryllium, mustard gas, cadmium, nickel, etc. [11]. Surgical approaches, such as segmentectomy, sleeve resection, lobectomy, pneumonectomy, and non-surgical approaches, including radiation therapy, chemotherapy, and immunotherapy, have been implemented as the treatment strategies in NSCLC [12,13]. The early diagnosis and treatment of NSCLC can contribute to better survival rates and prognosis.

Signal transducer and activator of transcription (STAT) is a family of cytoplasmic transcription factors comprising of seven variants (STAT1, STAT2, STAT3, STAT4, STAT5a, STAT5b, and STAT6). STAT3 is a latent oncogenic protein transiently activated in various types of normal cells [14-18]. The stimulation of transmembrane receptors by cytokines (IL-6 family members) or growth factors (EGF and HGF) lead to the activation of a non-receptor tyrosine kinase, such as Src and Janus kinase (JAK). The activated upstream kinases phosphorylate STAT3 at Tyr705 to undergo dimerization, and translocation into nucleus to transcribe the genes that are involved in proliferation (cyclin D1/E1), inflammation (COX2, IL-1/6 and M-CSF), antiapoptosis (survivin and Bcl-xL), angiogenesis (VEGF, bFGF, and HIF1 $\alpha$ ), metastasis (MMP2/9), and tumor evasion (IP-10 and RANTES) [19-22]. Overactivation of STAT3 has been associated with chronic inflammation, which drives the transformation of healthy to cancerous cells [23-30]. Of note, persistent activation of STAT3 has been observed in various types of solid (lung, liver, prostate, breast, head and neck, and gastric) and hematological (leukemia, lymphoma, multiple myeloma) malignancies [31-35]. Given the relevance of STAT3 signaling in oncogenesis, abrogation of the STAT3 signaling cascade may be useful to counteract diverse malignancies.

In an attempt to identify new STAT3 signaling inhibitors, we performed high-throughput virtual screening (HTVS) of a library of small molecules using a cheminformatics platform and identified 2-Amino-6-[2-(Cyclopropylmethoxy)-6-Hydroxyphenyl]-4-Piperidin-4-yl Nicotinonitrile (ACHP) as the lead inhibitor of STAT3. We further tested a predicted lead compound against lung cancer cells for possible STAT3 signaling inhibitory activity and it was found to have pronounced inhibition of the signaling cascade.

\section{Materials and Methods}

\subsection{Reagents}

ACHP, as shown in Figure 1A, was purchased from TOCRIS Bioscience (Ellisville, MO, USA). The stock solution of ACHP $(1 \mathrm{mM})$ was prepared in dimethyl sulfoxide, stored at $-80^{\circ} \mathrm{C}$, and diluted in cell culture medium for use. RPMI1640, DMEM (Dulbecco Modified Eagle Medium)/low, MEM media, fetal bovine serum (FBS), and antibiotic-antimycotic mixture were obtained from Thermo Scientific HyClone (Waltham, MA, USA). A LightShift ${ }^{\circledR}$ Chemiluminescent EMSA kit was obtained from Thermo Fisher Scientific Inc. (Waltham, MA, USA). 5'-biotinylated STAT3 was obtained from Bioneer Corporation (Daejeon, Korea). IL-6 was purchased from R\&D Systems (Minneapolis, MN, USA). A FITC Annexin V Apoptosis Detection Kit I was purchased from BD Biosciences (San Diego, CA, USA). TUNEL enzyme and TUNEL label were purchased from Roche (Basel, Switzerland). Green-fluorescent Alexa Fluor 488 anti-Goat IgG1 and red-fluorescent Alexa Fluor 594 anti-Rabbit IgG1 antibodies were purchased from Invitrogen (Carlsbad, CA, USA). Antibodies against p-STAT3(Tyr705), STAT3, $\beta$-actin, p-Src (Tyr416), PARP, caspase-3, survivin, Bcl-2, Bcl-xl, HRP-conjugated goat anti-rabbit, and anti-mouse antibodies were purchased from Santa Cruz Biotechnology (Santa Cruz, CA, USA). Antibodies against p-JAK1 (Tyr1022/1023), JAK1, p-JAK2 (Tyr1007/1008), JAK2, cyclin D1, and cleaved caspase-3 were obtained from Cell Signaling Technology (Beverly, MA). The nitrocellulose 
membrane was obtained from Pall Corporation (Ann Arbor, MI, USA). Chemiluminescent substrate (ECL) was purchased from GE Healthcare (Waukesha, WI, USA). The oligonucleotide sequences used for EMSA are 5'-biotinylated STAT3 (5'-GATCCTTCTGGGAATTCCTAGATC-3' and $5^{\prime}$-GATCTAGGAATTCCCAGAAGGATC-3') in complex with nuclear protein and Oct-1 (5'-TTCTAGTGATTTGCATTCGACA-3' and 5' -TGTCGAATGCAAATCACTAGAA-3' ${ }^{\prime}$.

\subsection{Cell Lines and Culture Conditions}

Human lung cancer cell lines A549, H1299, and human embryo lung cell lines HEL 299 were purchased from the American Type Culture Collection (Manassas, VA, USA). A549 cells were cultured in DMEM/low medium, H1299 cells in RPMI1640 medium, and HEL 299 cells in MEM medium. All cells were cultured in medium containing $10 \%$ fetal bovine serum (FBS) and 1\% penicillin-streptomycin (P/S) maintained at $37^{\circ} \mathrm{C}$ in a $5 \% \mathrm{CO}_{2}$ atmosphere. At $~ 70-90 \%$ confluence, the cells were subcultured using $0.05 \%$ trypsin/EDTA.

\subsection{High-Throughput Virtual Screening (HTVS) of Small Molecules Targeting STAT3}

The MOLPRINT-2D based cheminformatics tool was used to identify the STAT3 targeting of small molecules as reported earlier [36]. In brief, the bioactivity data of ChEMBL was used, where the cut-off values $\left(\mathrm{IC}_{50} / \mathrm{EC}_{50} / \mathrm{Ki} / \mathrm{Kd}\right)$ less than or equal to $10 \mu \mathrm{M}$ were considered as active and the greater than $10 \mathrm{mM}$ as inactive compounds. MOLPRINT 2D descriptors were obtained for all the datasets using reported protocols $[37,38]$. Using the Naïve Bayes classifier, the trained datasets were queried with the ZINC database molecules, comprising about 7300 compounds, to obtain the ranked compounds.

\subsection{Cell Viability Assay}

A cell viability assay was performed to evaluate the effect of ACHP on the NSCLC cells as described earlier [39-41]. Cells were seeded at a density of $5 \times 10^{3}$ cells per well in 96-well plates and were incubated at $37^{\circ} \mathrm{C}$ in $5 \% \mathrm{CO}_{2}$ overnight to induce cell adherence. Cells were treated with different concentrations of ACHP for $24 \mathrm{~h}$. For the MTT assay, thiazolyl blue tetrazolium bromide solution $(2 \mathrm{mg} / \mathrm{mL})$ was added and this mixture was incubated for $2 \mathrm{~h}$. After this, lysis buffer ( $20 \%$ SDS and $50 \%$ dimethylformamide) was added to the cells. The cells were incubated overnight at $37^{\circ} \mathrm{C}$, and the absorbance was then measured at $570 \mathrm{~nm}$ using a Varioskan LUX Multimode Microplate Reader (Thermo Fisher Scientific).

\subsection{Preparation of Whole Cell Lysates}

For the detection of expression of proteins, ACHP-treated whole-cell lysates were prepared as reported previously [42,43] using a lysis buffer [Tris (20 mM, pH 7.4), $\mathrm{NaCl}(250 \mathrm{mM})$, EDTA (2 mM, pH 8.0), Triton X-100 (0.1\%), aprotinin $(0.01 \mathrm{mg} / \mathrm{mL})$, leupeptin $(0.005 \mathrm{mg} / \mathrm{mL})$, phenylmethane sulfonyl fluoride $(0.4 \mathrm{mM})$, and $\left.\mathrm{NaVO}_{4}(4 \mathrm{mM})\right]$. The lysates were centrifuged at 13,000 rpm for $15 \mathrm{~min}$ to remove insoluble material.

\subsection{Western Blot Analysis}

The protein concentration was estimated in cell lysates and equal concentrations of proteins were resolved on $8-15 \%$ sodium dodecyl sulfate-polyacrylamide gel electrophoresis followed by their transfer to a nitrocellulose membrane as reported earlier [44-46]. The membranes were treated with $5 \%$ skim milk and incubated with the desired antibodies at $4{ }^{\circ} \mathrm{C}$ overnight. The next day, membranes were washed in an appropriate buffer and probed with HRP-conjugated secondary antibody for $2 \mathrm{~h}$, followed by their examination using chemiluminescent substrate. 
A.

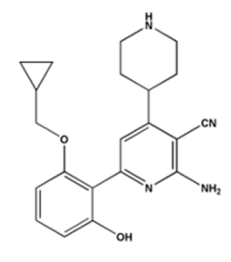

ACHP [MW : 364]
B.

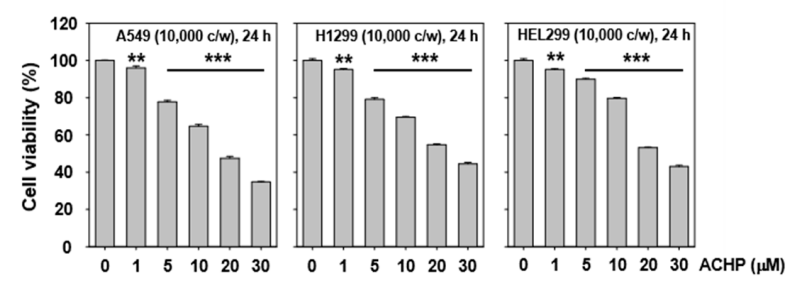

C.

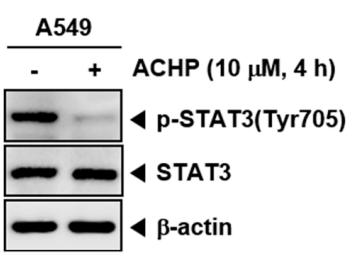

D.

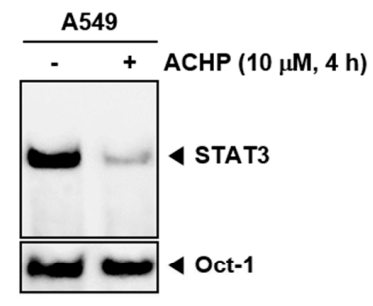

E.

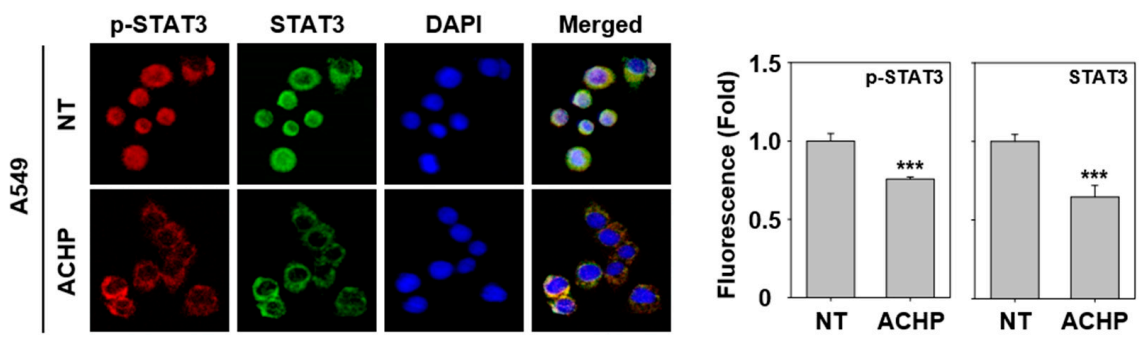

F.

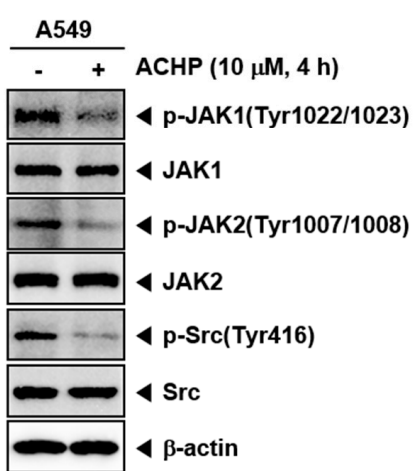

Figure 1. ACHP suppresses cell viability and blocks the STAT3 signaling pathway. (A) The chemical structure of ACHP. (B) A549, H1299, and HEL 299 cells were treated with various concentrations of ACHP for $24 \mathrm{~h}$, and cell viability was determined by MTT assay. The results shown are representative of three independent experiments. ${ }^{* *} p<0.01,{ }^{* * *} p<0.001$. (C) A549 cells were treated with $10 \mu \mathrm{M}$ of ACHP for $4 \mathrm{~h}$. Thereafter, equal amounts of lysates were analyzed by western blot analysis using antibodies against p-STAT3(Tyr705) and STAT3. The same blots were stripped and reprobed with $\beta$-actin antibody to verify equal protein loading. -: Non-treatment, +: ACHP treatment. (D) A549 cells were treated with $10 \mu \mathrm{M}$ of ACHP for $4 \mathrm{~h}$ and then tested for DNA binding to STAT3 by electrophoretic mobility shift assay (EMSA). (E) A549 cells were treated as described above in panel $C$ and then analyzed for intracellular distribution by immunocytochemistry. The results shown are representative of three independent experiments. ${ }^{* * *} p<0.001$. Quantitative analysis of the fluorescence intensity of p-STAT3 and STAT3 were performed. The merged image indicates the overlapping of p-STAT3/STAT3/DAPI images. The results shown are representative of three independent experiments. ${ }^{* * *} p<0.001$. (F) A549 cells were treated as described above in panel $\mathrm{C}$, and western blot was performed using various antibodies. -: Non-treatment, +: ACHP treatment. 


\subsection{Electrophoretic Mobility Shift Assay (EMSA)}

EMSA was performed to analyze the interaction of STAT3-DNA as described previously $[47,48]$. Briefly, cells were subjected to ACHP treatment $(10 \mu \mathrm{M}$ for $4 \mathrm{~h})$ and the nuclear extract was prepared. 5 '-biotinylated STAT3 oligonucleotide in complex with nuclear protein and Oct-1 was used for the loading control. The protein-oligonucleotide complex was subjected to PAGE and blotted to a nylon membrane, followed by cross-linkage with UV. Lastly, the mobility of proteins was examined using a LightShift ${ }^{\circledR}$ Chemiluminescent EMSA kit (Waltham, MA, USA) [47].

\subsection{Immunocytochemistry for the Distribution of STAT3}

The distribution of phosphorylated STAT3 in the cells were analyzed as described earlier [49]. In brief, cells were subjected to ACHP treatment $(10 \mu \mathrm{M}$ for $4 \mathrm{~h})$, followed by fixing using paraformaldehyde $(4 \%)$ for $20 \mathrm{~min}$. Thereafter, cells were treated with $0.2 \%$ Triton $\mathrm{X}-100$ in phosphate-buffered saline for permeabilization, followed by blocking with $5 \%$ bovine serum albumin for $1 \mathrm{~h}$. Then, the preparation was incubated overnight at $4{ }^{\circ} \mathrm{C}$ with a rabbit polyclonal anti-human STAT3 antibody (dilution, 1:100). The next day, slides were subjected to washing and incubation with Alexa Fluor 594 (dilution, 1:1000) anti-Rabbit IgG1 for $1 \mathrm{~h}$ at room temperature in the dark. In the next step, DAPI $(5 \mu \mathrm{g} / \mathrm{mL})$ was used for counterstaining the nuclei. The slides were mounted and analyzed under an Olympus FluoView FV1000 confocal microscope (Tokyo, Japan).

\subsection{Monitoring of Cell Growth with the RTCA DP Instrument}

The growth of A549 and H1299 cells were constantly assessed for $48 \mathrm{~h}$ using the xCELLigence RTCA DP Instrument (Roche Diagnostics GmbH, Mannheim, Germany). The reading was taken using $100 \mu \mathrm{L}$ cell culture medium per well and the final volume in the well was made up to $200 \mu \mathrm{L}$ using the cell culture medium bearing $5 \times 10^{3}$ cells/well. The impedance was measured continuously in $15 \mathrm{~min}$ intervals. Cell index (CI) values were normalized to the time point of $10 \mu \mathrm{M}$ of ACHP treatment.

\subsection{0. siRNA Transfection}

A549 cells were seeded and transiently transfected with STAT3 or scrambled siRNAs using a transfection reagent (Intron Biotechnology, Seoul, Korea). At $24 \mathrm{~h}$ post-transfection, the cells were treated with $10 \mu \mathrm{M}$ of ACHP for $24 \mathrm{~h}$ or $36 \mathrm{~h}$ and then an MTT and TUNEL assay was performed.

\subsection{Annexin $V$ Assay}

The apoptosis-inducing effect of ACHP on A549 and H1299 cells was evaluated using an Annexin assay as described previously [46,50]. The A549 and H1299 cells were exposed to ACHP $(10 \mu \mathrm{M})$ for indicated time points and collected using trypsin $(1 \%)$ in phosphate-buffered saline, followed by giving a single wash with cold phosphate-buffered saline. The cell pellet was collected and suspended in binding buffer $(1 \times)$. Thereafter, FITC Annexin V $(5 \mu \mathrm{L})$ and propidium iodide $(5 \mu \mathrm{L})$ were added and incubated in the dark at room temperature for $15 \mathrm{~min}$ to stain the cells. Stained samples were analyzed by a BD Accuri C6 plus flow cytometer (BD Biosciences, San Diego, CA, USA). The interpretation of the data was performed using BD Accuri C6 plus software (version 1.0.23.1).

\subsection{TUNEL Assay}

The apoptosis-inducing effect of ACHP was further evaluated using a Roche Diagnosis TUNEL (terminal transferase-mediated dUTP-fluorescein nick end labelling) assay kit as reported earlier [49]. A549 and H1299 cells were exposed to ACHP $(10 \mu \mathrm{M})$ for indicated time points and washed with cold phosphate-buffered saline, followed by fixing using paraformaldehyde (4\%) for $30 \mathrm{~min}$ and washing twice with phosphate-buffered saline. Thereafter, cells were treated with $0.1 \%$ Triton X-100 and $0.1 \%$ sodium citrate for permeabilization for $20 \mathrm{~min}$ at $4{ }^{\circ} \mathrm{C}$, followed by washing with cold phosphate-buffered saline. The preparation was treated with a TUNEL enzyme and TUNEL label 
mixture for $1 \mathrm{~h}$ at $37^{\circ} \mathrm{C}$ in the dark, followed by washing with phosphate-buffered saline and analyzed using BD Accuri C6 plus software (version 1.0.23.1).

\subsection{In Silico Interaction Analysis}

Discovery Studio 2.5 software from Accelrys was used for docking and visualization of the results as described earlier [51,52]. Initially, we obtained the crystal structure of the STAT3 homodimer bound to DNA (PDB ID: 1BG1) [53], cleaned, minimized the energy, and identified the spatial region of STAT3. The CHARMM force field function was used to calculate the energy calculations. The three-dimensional structure of ligands (ACHP and $\mathrm{HAB}$ ) were produced and docked towards the SH2 domain of STAT3 using the LIGANDFIT protocol. The interaction map and binding position of ACHP and HAB were evaluated using the interaction score function in the Ligand Fit module of Discovery Studio as reported previously [54].

\subsection{Statistical Analysis}

The Student's $t$-test and one-way analysis of variance (ANOVA) tests were used for statistical analysis and comparisons between groups. $p<0.05$ was considered significant. Data are expressed as the mean $\pm \mathrm{SD}$ and vertical error bars denote $\mathrm{SD}$.

\section{Results}

\subsection{In Silico Approach for the Identification of Ligands Targeting STAT3}

The cheminformatics-based MOLPRINT-2D program was used to identify the lead compounds that target STAT3. For this, active and inactive datasets for a STAT3 model were built and queried with the ZINC database as described earlier [55]. The ranked compounds are provided as a supplementary file and the structure of the top four ranked compounds that target STAT3 are provided as a supplementary figure. Among the queried compounds, ACHP was ranked first and therefore, it was procured from the private firm and used for evaluation of its STAT3 inhibitory activity.

\subsection{ACHP Reduces NSCLC Cell Viability}

To examine the effect of ACHP on the growth of human lung cancer cells and human embryonic lung fibroblasts, the growth inhibitory potential was determined in A549, H1299, and HEL299 cells. We found the concentration-dependent reduction in cell viability on treatment with ACHP for $24 \mathrm{~h}$. The A549 cell viability values of ACHP were 95\%, 77\%, 64\%, $47 \%$, and $34 \%$, and the viability values of $\mathrm{H} 1299$ cells were $95 \%, 79 \%, 69 \%, 54 \%$, and $44 \%$, at the concentration of $1,5,10,20$, and $30 \mu \mathrm{M}$, respectively.

\subsection{ACHP Inhibits Constitutively Active STAT3 in NSCLC}

Persistent activation of STAT3 contributes to uncontrolled cell proliferation, angiogenesis, apoptotic resistance, and prosurvival effect in cancer cells [26]. Therefore, we evaluated whether ACHP can suppress the constitutive activation of STAT3. In A549 cells, ACHP treatment reduced the STAT3 phosphorylation at Tyr705 without affecting the total STAT3 protein expression. These results clearly suggest that ACHP significantly downregulates the constitutive phosphorylation of STAT3 in lung cancer cells, as shown in Figure 1C. ACHP also clearly reduced the constitutive STAT3 DNA-binding activity, as shown in Figure 1D.

\subsection{ACHP Blocks the Nuclear Localization of STAT3 in A549 Cells}

Activated STAT3 dimers can enter the nucleus to transcribe its target genes [56,57]. To confirm that nuclear-translocated STAT3 is inhibited by ACHP, we next analyzed the distribution of phospho-STAT3 in the nucleus and cytoplasm using fluorescent-labeled antibodies. As shown in Figure 1F, ACHP suppressed the nuclear translocation of STAT3 in A549 cells, as shown in Figure 1E. 


\subsection{ACHP Represses Constitutive JAK1, JAK2, and Src Activation}

STAT3 is phosphorylated by the upstream tyrosine kinases, such as JAK1, JAK2, and Src $[58,59]$. We next investigated the effect of ACHP on the activation of JAK1, JAK2, and Src in A549 cells. ACHP treatment resulted in the downregulation of JAK1, JAK2, and Src phosphorylation, whereas ACHP did not affect these total forms, as shown in Figure 1F.

\subsection{ACHP Inhibits IL-6-Induced Activation of STAT3 and Upstream Kinases}

We further investigated the effect of ACHP on IL-6-driven activation of STAT3 in H1299 cells. To analyze this, H1299 cells were treated with ACHP $(10 \mu \mathrm{M})$ for $6 \mathrm{~h}$ followed by stimulation with IL-6 for $15 \mathrm{~min}$. We found that ACHP completely reverted the IL-6-driven phosphorylation of STAT3 in the tested cells, as shown in Figure 2A. The effect of ACHP on IL-6 driven STAT3 activation was further justified using an electrophoretic mobility shift assay (EMSA) and ACHP downregulated IL-6-induced STAT3 activation, as shown in Figure 2B. In addition, JAK1, JAK2, and Src, the kinases of the upstream signaling pathway of STAT3, were maximally activated at $15 \mathrm{~min}$ after exposure of H1299 cells to IL-6, whereas it was inhibited by ACHP, as shown in Figure 2C. Interestingly, as shown in Figure 2D, ACHP blocked translocation of IL-6-induced STAT3 to the nucleus in H1299 cells.

\subsection{ACHP Blocks the Proliferation Activity of NSCLC.}

We next evaluated the antitumor activity of ACHP towards A549 and H1299 cells. The cancer cells were incubated with $\mathrm{ACHP}(10 \mu \mathrm{M})$ and viability was measured at intervals of 15 min using the xCELLigence RTCA MP Instrument (Roche Diagnostics GmbH, Germany). ACHP substantially suppressed the proliferation of A549, compared with the untreated cells, as shown in Figure 3A. Interestingly, ACHP decreased the IL-6 induced proliferation of H1299 cells.

\subsection{Transfection with STAT3 siRNA Blocks ACHP-Induced Cytotoxicity}

We determined whether the knockdown of STAT3 using siRNA could significantly block the increase in ACHP induced cytotoxicity in A549 cells. In A549 cells transfected with scrambled siRNA, ACHP treatment significantly reduced cell viability, but not in the cells transfected with STAT3 siRNA, thereby establishing STAT3 as a pivotal target affected by ACHP, as shown in Figure 3B.

\subsection{ACHP Induces Apoptosis and Decreases the Expression of Tumorigenic Proteins}

We further examined the apoptosis induction potential of ACHP in A549 and H1299 cells using annexin V and TUNEL assays. Annexin V assay results presented that ACHP enhanced the apoptotic population to $24.1 \%(5.2 \%+18.9 \%)$ in A549 cells at the dose of $10 \mu \mathrm{M}$ for $36 \mathrm{~h}$ compared with the untreated control cells, as shown in Figure 3C-i. The percentage of apoptotic cells in H1299 cells reached $13.9 \%(8.8 \%+5.1 \%)$ by ACHP and decreased to $10.3 \%(6.8 \%+3.5 \%)$ in the combined treatment of IL-6, as shown in Figure 3D-i. The results of the TUNEL assay also indicated that the apoptotic population was increased from $2.0 \%$ to $6.4 \%$ at $24 \mathrm{~h}$ and $7.8 \%$ at $36 \mathrm{~h}$ after the administration of the drug in A549 cells, as shown in Figure 3C-ii. In H1299 cells, the apoptotic population increased to 9.5\% by ACHP, whereas it decreased to $7.2 \%$ by IL-6, as shown in Figure 3D-ii.

We also evaluated the effect of ACHP on the expression of antiapoptotic proteins in NSCLC. We observed that the ACHP decreased the levels of prosurvival proteins, such as survivin, Bcl-2, Bcl-xl, and cell cycle regulator, cyclin D1, in a time-dependent manner in A549 cells, as shown in Figure 3D. On the other hand, IL-6 treatment induced the expression of survivin, Bcl-2, Bcl-xl, and cyclin D1, whereas ACHP significantly abrogated their expression, as shown in Figure 3E.

\subsection{ACHP Triggers the Activation of Procaspase-3 and Induces PARP Cleavage}

We next examined whether the blocking of STAT3 activation by ACHP leads to caspase-3 mediated apoptosis in NSCLC. We observed the cleavage of full-length procaspase-3 with the corresponding 
increase in cleaved fragments on treatment with ACHP at $10 \mu \mathrm{M}$ for $36 \mathrm{~h}$, as shown in Figure 3F. In A549 and H1299 cells treated with ACHP, there were increased cleavage products of PARP and caspase-3, as shown in Figure 3G, whereas they were marginally affected by IL-6, as shown in Figure $3 \mathrm{H}$.

A.

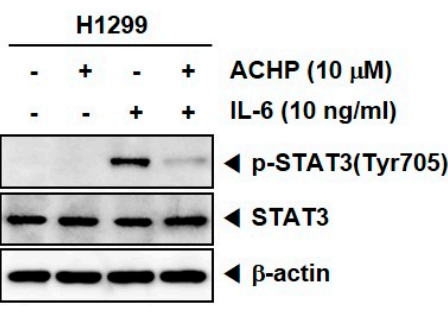

C.

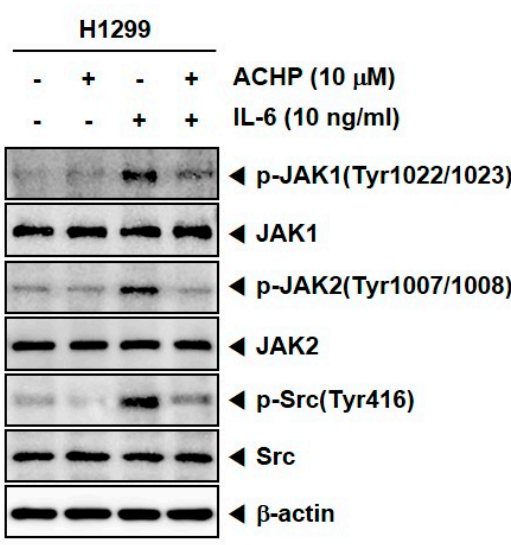

B.

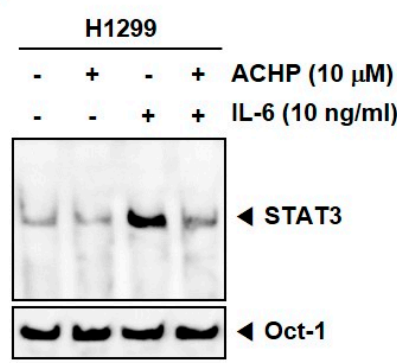

D.
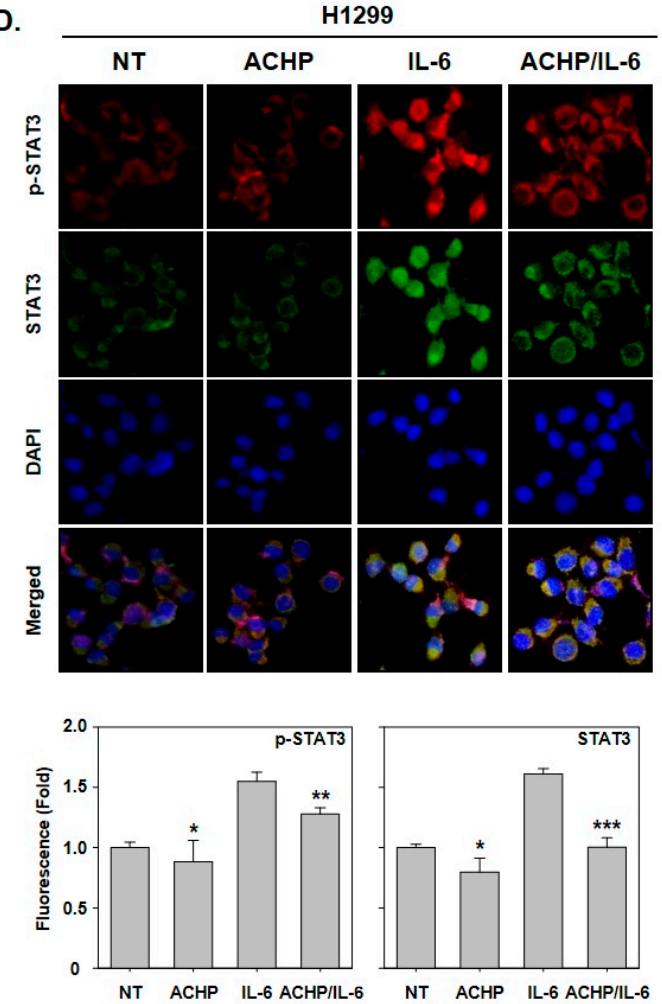

Figure 2. ACHP inhibits IL-6-induced STAT3 activation. (A) H1299 cells were treated with $10 \mu \mathrm{M}$ of ACHP for $4 \mathrm{~h}$ and then stimulated with IL-6 $(10 \mathrm{ng} / \mathrm{mL})$ for $15 \mathrm{~min}$. Thereafter, equal amounts of lysates were analyzed by western blot analysis using antibodies against p-STAT3(Tyr705) and STAT3. The same blots were stripped and reprobed with $\beta$-actin antibody to verify equal protein loading. (B) H1299 cells were treated with $10 \mu \mathrm{M}$ of ACHP for $4 \mathrm{~h}$ and then stimulated with IL- $6(10 \mathrm{ng} / \mathrm{mL})$ for $15 \mathrm{~min}$ and then tested for DNA binding to STAT3 by EMSA. (C) H1299 cells were treated as described above in panel A, and western blot was performed using various antibodies. (D) H1299 cells were treated as described above in panel A and then analyzed for intracellular distribution by immunocytochemistry. The results shown are representative of three independent experiments. ${ }^{* * *} p<0.001$. Quantitative analysis of the fluorescence intensity of STAT3 was performed. The merged image indicates the overlapping of p-STAT3/STAT3/DAPI images. ${ }^{*} p<0.05,{ }^{* *} p<0.01,{ }^{* * *} p<0.001$. - : Non-treatment, +: ACHP treatment. 
A.

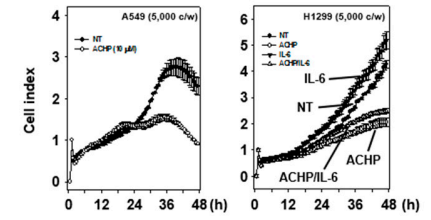

c.

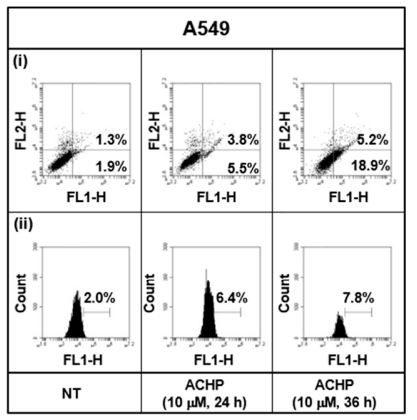

D.

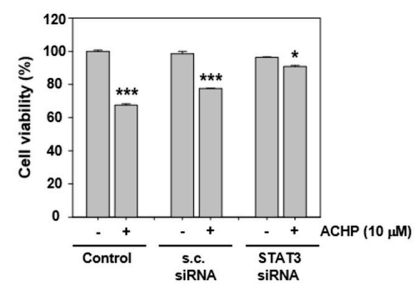

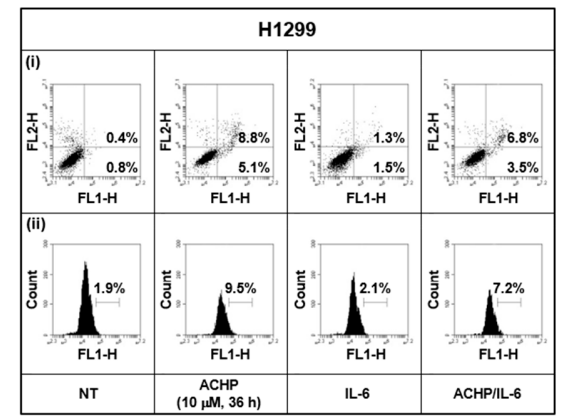

E.
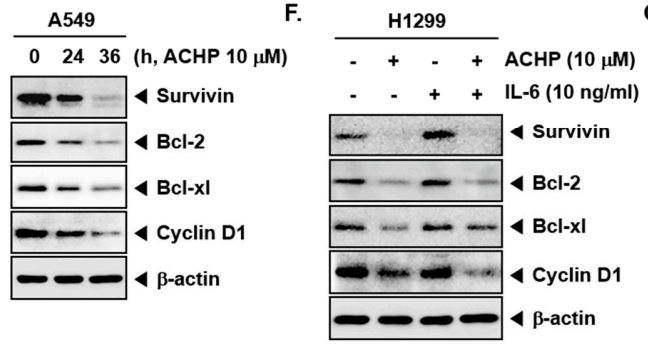

G.

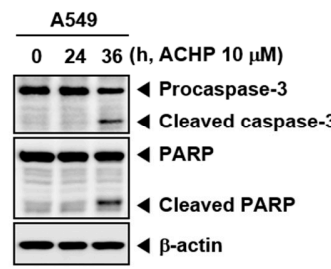

H.

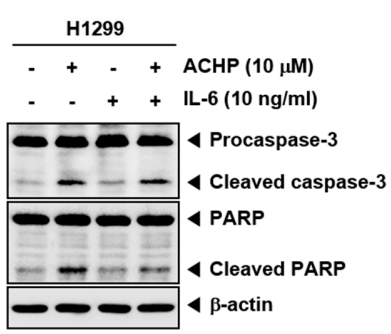

I.

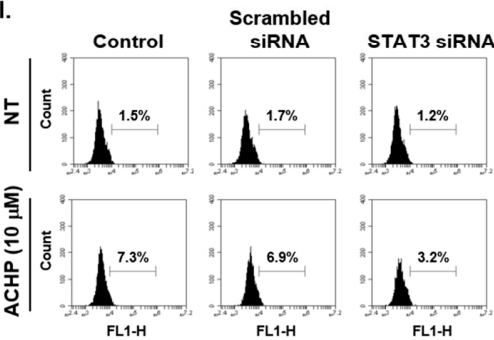

Figure 3. ACHP inhibits cell proliferation and induces apoptosis in non-small cell lung cancer (NSCLC). (A) A549 cells were treated with $10 \mu \mathrm{M}$ of ACHP (left) and H1299 cells were treated with $10 \mu \mathrm{M}$ of ACHP or $10 \mathrm{ng} / \mathrm{mL}$ of IL-6 (right). Then, a cell proliferation assay was performed using Roche xCELLigence Real-Time Cell Analysis (RTCA). (B) A549 cells were transfected with either scrambled siRNA or STAT3-specific siRNA $(50 \mathrm{nM})$. After $24 \mathrm{~h}$, the cells were treated with $10 \mu \mathrm{M}$ of ACHP for $24 \mathrm{~h}$, and cell viability was determined by MTT assay. The results shown are representative of three independent experiments. ${ }^{* * *} p<0.001$. (C) A549 cells were treated with $10 \mu \mathrm{M}$ of ACHP for $24 \mathrm{~h}$ and $36 \mathrm{~h}$. (i) The cells were incubated with a FITC conjugated Annexin V, then examined for an early apoptotic effect with flow cytometry. FL1-H: Annexin V-FITC, FL2-H: PI. (ii) The cells were fixed and incubated with a TUNEL reaction solution, and then examined via flow cytometry. (D) H1299 cells were treated with $10 \mu \mathrm{M}$ of ACHP or $10 \mathrm{ng} / \mathrm{mL}$ of IL-6 for $36 \mathrm{~h}$. (i) The cells were incubated with a FITC conjugated Annexin V, then examined for an early apoptotic effect with flow cytometry. FL1-H: Annexin V-FITC, FL2-H: PI. (ii) The cells were fixed and incubated with a TUNEL reaction solution, and then examined via flow cytometry. (E) A549 cells were treated with $10 \mu \mathrm{M}$ of ACHP for $24 \mathrm{~h}$ and $36 \mathrm{~h}$, then western blotting was performed using various antibodies. (F) H1299 cells were treated with $10 \mu \mathrm{M}$ of ACHP or $10 \mathrm{ng} / \mathrm{mL}$ of IL-6 for $36 \mathrm{~h}$, then western blotting was performed using various antibodies. (G) A549 cells were treated as described above in panel E, and a western blot was done. (H) H1299 cells were treated as described above in panel F, and a western blot was done. Data are expressed as the mean \pm SD and vertical error bars denote SD. (I) A549 cells were transfected with either scrambled siRNA or STAT3-specific siRNA ( $50 \mathrm{nM}$ ). After $24 \mathrm{~h}$, the cells were treated with $10 \mu \mathrm{M}$ of ACHP for $36 \mathrm{~h}$ and incubated with TUNEL reaction solution, and then examined via flow cytometry. ${ }^{*} p<0.05,{ }^{* *} p<0.01$, *** $p<0.001$. -: Non-treatment, +: ACHP treatment. 


\subsection{Knockdown of STAT3 Reverses the Apoptotic Effect of ACHP}

We determined whether the knockdown of STAT3 using siRNA could significantly block the increase in ACHP-induced apoptosis in A549 cells. As shown in Figure 3I, the ACHP treatment alone resulted in substantial apoptosis $(7.3 \%)$, whereas only $3.2 \%$ of the cells in the STAT3 knockdown group were found to be apoptotic. These findings indicate that STAT3 could be one of the major molecular targets that can be affected by ACHP.

\subsection{ACHP Interacts with the SH2 Domain of STAT3 In Silico}

We performed in silico analysis to determine the possible molecular interactions between the ACHP and SH2 domain of STAT3. ACHP and 2-hydroxy-4-(2-(tosyloxy) acetamido)benzoic acid (HAB), a known STAT3 inhibitor, were docked with the crystal structure of a STAT3 monomer that bound to a DNA oligomer (PDB ID: 1BG1) using the CDOCKER protocol of Accelrys discovery studio 2.5 version, as shown in Figure 4A. Molecular docking analysis gave the ligand-protein binding-energy value, interactions, and also the putative bound conformations of them. The negative CDOCKER energy score for ACHP and HAB towards the SH2 domain of STAT3 and ACHP presented a relatively higher score than its counterpart. The ACHP and HAB shared a similar binding pattern and interacted with Pro471, Ile467, Met470, Trp474, Arg335, Asp570, Ile569, and Asp566, as shown in Figure 4B. A hydrogen bond was established between Thr515 and the amino group of ACHP, and amide of HAB. Additionally, the tosyloxy group and carboxylic acid of HAB established a hydrogen bond with Arg335 and Asp570, respectively. These results suggested that ACHP may have physical interaction with STAT3 protein to induce its inhibitory activity.

A.

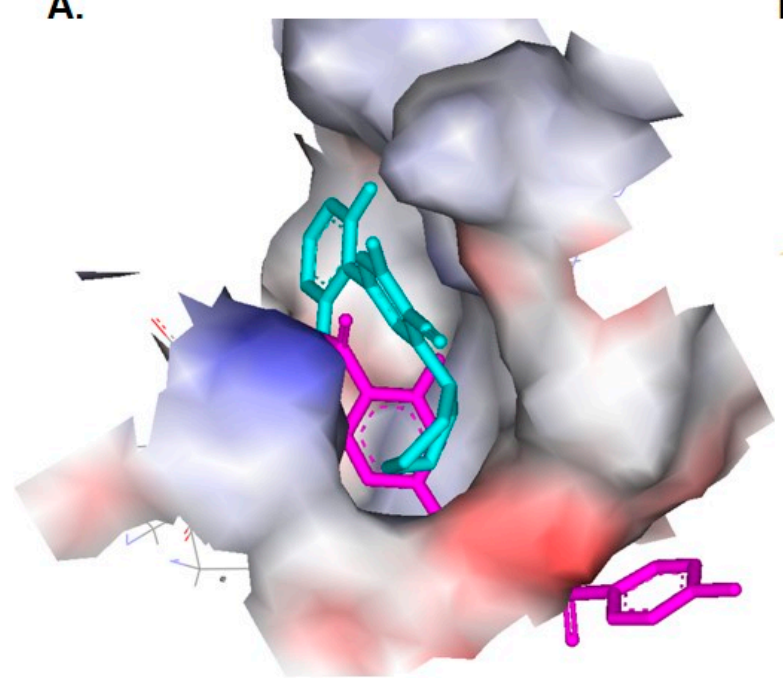

B.

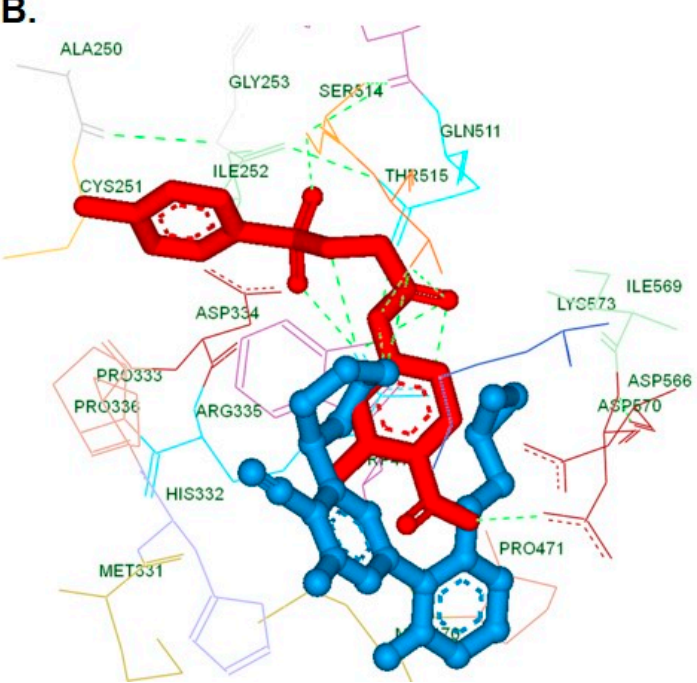

Figure 4. In silico interaction analysis between the SH2 domain of STAT3 and the ligands. (A) Surface view of the ACHP/HAB bound SH2 domain of STAT3. (B) Interaction map and hydrogen bonding (dotted line) pattern of the SH2 domain of STAT3 with ACHP and HAB.

\section{Discussion}

The therapeutic efficacy of the blockade of the STAT3 signaling pathway in cancers has been extensively studied, and a number of STAT3 inhibitors have been developed [60-63]. In the present investigation, we determined the cytotoxic effect of ACHP on the panel of NSCLC cells and found that ACHP possesses a good cytotoxic effect on the tested cancer cell lines. ACHP was found to mediate its cytotoxicity by abrogating the STAT3 signaling pathway. ACHP is a piperidinyl nicotinonitrile derivative, which was initially identified as a selective inhibitor of IKK- $\beta$ with good aqueous solubility, cell permeability, and oral bioavailability profile in mice and rats $[64,65]$. In addition, 
ACHP has also been demonstrated to show inhibitory action towards other kinases, such as IKK- $\alpha$ (IC ${ }_{50}$ : $\left.250 \mathrm{nM}\right), \mathrm{IKK} 3$, Syk, and MKK4 $\left(\mathrm{IC}_{50}>20 \mu \mathrm{M}\right)$ [66]. Previous studies also suggest that ACHP exhibited cytotoxicity in adult T-cell leukemia and multiple myeloma cells by interfering with NF- $\mathrm{kB}$ signaling [65,67]. The activation of NF- $\mathrm{KB}$, in addition to controlling tumorigenesis [68-72], plays a key role in the induction of fibrosis and ACHP displayed strong antifibrotic effects by suppressing the TGF $\beta 1$-induced differentiation of fibroblasts into myofibroblasts and collagen synthesis [73]. Recently, ACHP has been reported to block NF- $\mathrm{kB}$ signaling in mouse and human keratinocytes and inhibit multiple sources of cutaneous inflammation in mouse skin [74]. Besides, persistent activity of NF-KB and STAT3 has been linked with oncogenesis [75,76], and abrogation of either of these pathways may not lead to significant cytotoxicity [77]. In addition, a small molecule inhibitor (JSI-124 or cucurbitacin I) of STAT3 signaling was reported to activate the NF- $\mathrm{kB}$ pathway [78]. Therefore, it may be an effective strategy to have a dual inhibitor of STAT3 and NF- $\mathrm{kB}$ pathways to induce potent cytotoxicity [79]. Similarly, 2-[(aminocarbonyl)amino]-5-(4-fluorophenyl)-3-thiophenecarboxamide (TPCA-1) is a synthetic small molecule that has been reported as an ATP-competitive selective inhibitor of IKK2 [80], and subsequent discoveries presented TPCA-1 as a direct dual inhibitor of STAT3 and NF- $K B$ that effectively regresses mutant EGFR-associated human NSCLC [77]. Herein, we performed HTVS of small molecules bearing various scaffolds against STAT3 inhibition and identified ACHP as the lead hit. The predicted target was experimentally validated in NSCLC cellular models.

Overexpression of STAT3 has been reported to potentiate growth, survival, and chemo- and radio-resistance of NSCLC [81,82] and human squamous cell carcinoma cells [83,84]. A significant correlation was found between STAT3 protein expression and tumor differentiation, clinical stage, and lymph node metastasis of NSCLC patients [85]. Notably, the five-year overall survival rate of patients with low STAT3 expression was significantly higher than that of patients with high STAT3 expression indicating the role of STAT3 as a prognostic marker [85]. In addition, several studies have demonstrated the persistent phosphorylation of STAT3 in 22-65\% of NSCLC [81], and the deregulation of STAT3 has been associated with malignant transformation [86,87]. The phosphorylation of Tyr705 is a critical event in regulating the transcriptional activity of STAT3, and mitigation of phosphorylation can result in a decline in the STAT3 nuclear pool [88]. Therefore, blocking of nuclear translocation of STAT3 by inhibiting its phosphorylation could be a therapeutic approach. In addition, earlier studies have also demonstrated that STAT3 is present in phosphorylated, as well as in unphosphorylated form in the endosomes. This also suggested that, in addition to the signal transducer role, the membrane-associated cytoplasmic STAT3 may also have a role in STAT3 metabolism [89].

In our study, ACHP was found to significantly inhibit the phosphorylation of STAT3 at Tyr705, which was evidently demonstrated using multiple approaches, and the molecular mechanism by which the ACHP inhibits STAT3 signaling in NSCLC cells has been studied. In addition to the downregulation of phosphorylation, we also noticed the significant deprivation of nuclear STAT3 levels and reduction in DNA binding activity, which is evidence for the decline in the transcription of STAT3 driven genes. Furthermore, ACHP was found to reduce the cell viability of the tested cell lines and we speculated the cytotoxic effect is due to inhibition of STAT3 signaling. To verify this, we knocked down STAT3 using siRNA and tested the effect of ACHP on cell viability of A549 cells. We observed minimal effect on the viability of STAT3-depleted A549 cells, thus indicating the absence of off-target effects.

STAT3 protein can be positively modulated by phosphorylated upstream protein tyrosine kinases, such as Src (Tyr416) and JAK (JAK1: Tyr1022/1023; and JAK2: Tyr1007/1008) [90]. We observed a substantial decrease in the phosphorylation of Src and JAKs. H1299 cells lack the constitutive activity of STAT3 signaling, and we observed the phosphorylation of Src, JAK1, and JAK2 on treatment with IL-6. It is noteworthy that ACHP has been previously demonstrated to exhibit inhibitory activity towards serine/threonine kinases (IKK- $\alpha / \beta)$, as well as tyrosine kinase (Syk) [66]. In the present effort, we have explored another cellular target kinase of ACHP. Furthermore, ACHP treatment suppressed the IL-6 induced activation of these cascades of proteins in H1299 cells. Activation of executioner caspase 
(caspase 3/7) is the major biochemical event associated with the cells committed to apoptosis [91], and the activated caspase- 3 cleaves PARP to induce apoptosis [54,92].

We noticed that ACHP induced the activation of caspase- 3 and cleavage of PARP. Evidently, we also observed the negative modulation in the expression of apoptosis modulators such as Bcl-2, Bcl-xl, and cyclin D1. In addition to its role in the activation of oncogenic gene expression, STAT3 has also been demonstrated to repress the expression of tumor suppressor genes to encourage the survival of cancer cells [93-95]. In contrast, some of the studies have highlighted STAT3 as a tumor suppressor protein. In one of the early studies, simultaneous shRNA-mediated knockdown of PTEN and deletion of STAT3 showed substantial increase in in vitro proliferation cells and tumor formation in SCID (Severe combined immunodeficient) mice in astrocytes. In parallel, knockdown of PTEN alone with normal STAT3 expression displayed significantly reduced tumorigenic potential, indicating that STAT3 serves as a tumor suppressor in the absence of PTEN [96]. In similar studies, the tumor suppressor functions of STAT3 were found to have relevance with Ras and p19ARF protein expression [97].

In 2018, Caetano et al. developed a lung epithelial-specific K-ras mutant/STAT3 conditional knockout mouse model, and deletion of epithelial STAT3 resulted in sex-associated discrepancies in which K-ras mutant tumors were decreased in female K-ras mutant/STAT3 conditional knockout, whereas tumor burdens were increased in males [98]. These reports spread light on the multifaceted role of STAT3 in oncogenic and tumor suppressor effects. However, our study highlights the constitutive activation of STAT3 in lung cancer cells and ACHP induced cell death via blocking oncogenic STAT3 signaling. We have previously reported several natural compounds that induce their inhibitory activity towards upstream kinases (JAK/Src) in cell-based assays and displayed interaction with the SH2 domain of STAT3 in computational studies. We obtained similar results in the present study and the exact mechanisms through which ACHP can interrupt STAT3 signaling either through interaction with its $\mathrm{SH} 2$ domain or attenuation of phosphorylation of upstream kinases requires further investigations. With these shreds of evidence, we have conclusively reported that STAT3 is the additional signaling cascade impeded by ACHP. In summary, our study shows the feasibility of inhibiting a constitutively active STAT3 signaling pathway in NSCLC cells.

Supplementary Materials: The Supplementary Materials are available online at http://www.mdpi.com/2218273X/9/12/875/s1.

Author Contributions: Designed and performed the experiments: J.H.L., C.D.M., S.B., and S.R. Designed the experiments and edited the manuscript: K.S.A., A.C., T.A.A., S.A.A., C.D.M., S.B., and K.S.R. Wrote the manuscript: C.D.M., A.P.K., G.S., and K.S.R.

Funding: This work was also supported by a National Research Foundation of Korea (NRF) grant funded by the Korean government (MSIP) (NRF-2017R1A6A3A11031224, NRF-2017M3A9E4065333, and 2018R1D1A1B07042969). The authors extend their appreciation to the International Scientific Partnership Program ISPP at King Saud University for funding this research work through ISPP\# 0091. B. thanks the Department of Biotechnology, Government of India and Vision Group on Science and Technology, Government of Karnataka for funding. A.P.K. was supported by grants from the National Medical Research Council of Singapore (R-713-000-214-51) and by the NCIS Yong Siew Yoon Research Grant through donations from the Yong Loo Lin Trust (R-713-000-173-720). A.P.K. was also supported by the National Research Foundation Singapore and the Singapore Ministry of Education under its Research Centre of Excellence Initiative to Cancer Science Institute of Singapore National University of Singapore.

Acknowledgments: K.S.R. thanks the University Grants Commission, New Delhi, and DST-Promotion of University Research and Scientific (PURSE), Institution of Excellence, University of Mysore for providing the BSR faculty fellowship and laboratory facility respectively.

Conflicts of Interest: The authors declare no conflict of interest. 


\section{References}

1. Siegel, R.; Ma, J.; Zou, Z.; Jemal, A. Cancer statistics, 2014. CA Cancer J. Clin. 2014, 64, 9-29. [CrossRef] [PubMed]

2. Yang, M.H.; Lee, J.H.; Ko, J.-H.; Jung, S.H.; Sethi, G.; Ahn, K.S. Brassinin Represses Invasive Potential of Lung Carcinoma Cells through Deactivation of PI3K/Akt/mTOR Signaling Cascade. Molecules 2019, 24, 1584. [CrossRef] [PubMed]

3. Jung, Y.Y.; Shanmugam, M.K.; Narula, A.S.; Kim, C.; Lee, J.H.; Namjoshi, O.A.; Blough, B.E.; Sethi, G.; Ahn, K.S. Oxymatrine Attenuates Tumor Growth and Deactivates STAT5 Signaling in a Lung Cancer Xenograft Model. Cancers 2019, 11, 49. [CrossRef] [PubMed]

4. Ko, J.-H.; Nam, D.; Um, J.-Y.; Jung, S.H.; Sethi, G.; Ahn, K.S. Bergamottin Suppresses Metastasis of Lung Cancer Cells through Abrogation of Diverse Oncogenic Signaling Cascades and Epithelial-to-Mesenchymal Transition. Molecules 2018, 23, 1601. [CrossRef]

5. Zappa, C.; Mousa, S.A. Non-small cell lung cancer: Current treatment and future advances. Transl. Lung Cancer Res. 2016, 5, 288-300. [CrossRef]

6. Wang, L.; Syn, N.L.; Subhash, V.V.; Any, Y.; Thuya, W.L.; Cheow, E.S.H.; Kong, L.; Yu, F.; Peethala, P.C.; Wong, A.L.; et al. Pan-HDAC inhibition by panobinostat mediates chemosensitization to carboplatin in non-small cell lung cancer via attenuation of EGFR signaling. Cancer Lett. 2018, 417, 152-160. [CrossRef]

7. Lee, H.; Baek, S.H.; Lee, J.H.; Kim, C.; Ko, J.-H.; Lee, S.-G.; Chinnathambi, A.; Alharbi, S.A.; Yang, W.M.; Um, J.-Y.; et al. Isorhynchophylline, a Potent Plant Alkaloid, Induces Apoptotic and Anti-Metastatic Effects in Human Hepatocellular Carcinoma Cells through the Modulation of Diverse Cell Signaling Cascades. Int. J. Mol. Sci. 2017, 18, 1095. [CrossRef]

8. Baek, S.H.; Ko, J.H.; Lee, J.H.; Kim, C.; Lee, H.; Nam, D.; Lee, J.; Lee, S.G.; Yang, W.M.; Um, J.Y.; et al. Ginkgolic Acid Inhibits Invasion and Migration and TGF-beta-Induced EMT of Lung Cancer Cells Through PI3K/Akt/mTOR Inactivation. J. Cell. Physiol. 2017, 232, 346-354. [CrossRef]

9. Ong, P.S.; Wang, L.; Chia, D.M.; Seah, J.Y.; Kong, L.R.; Thuya, W.L.; Chinnathambi, A.; Lau, J.Y.; Wong, A.L.; Yong, W.P.; et al. A novel combinatorial strategy using Seliciclib((R)) and Belinostat((R)) for eradication of non-small cell lung cancer via apoptosis induction and BID activation. Cancer Lett. 2016, 381, 49-57. [CrossRef]

10. Lee, J.H.; Kim, C.; Lee, S.G.; Yang, W.M.; Um, J.Y.; Sethi, G.; Ahn, K.S. Ophiopogonin D modulates multiple oncogenic signaling pathways, leading to suppression of proliferation and chemosensitization of human lung cancer cells. Phytomed. Int. J. Phytother. Phytopharmacol. 2018, 40, 165-175. [CrossRef]

11. Hubaux, R.; Becker-Santos, D.D.; Enfield, K.S.S.; Lam, S.; Lam, W.L.; Martinez, V.D. Arsenic, asbestos and radon: Emerging players in lung tumorigenesis. Environ. Health 2012, 11, 89. [CrossRef] [PubMed]

12. McDonald, F.; De Waele, M.; Hendriks, L.E.L.; Faivre-Finn, C.; Dingemans, A.-M.C.; Van Schil, P.E. Management of stage I and II nonsmall cell lung cancer. Eur. Respir. J. 2017, 49, 1600764. [CrossRef] [PubMed]

13. Tsoukalas, N.; Baxevanos, P.; Aravantinou-Fatorou, E.; Tolia, M.; Galanopoulos, M.; Tsapakidis, K.; Kyrgias, G.; Toumpanakis, C.; Kaltsas, G. Advances on systemic treatment for lung neuroendocrine neoplasms. Ann. Transl. Med. 2018, 6, 146. [CrossRef] [PubMed]

14. Sulaiman, N.B.; Mohan, C.D.; Basappa, S.; Pandey, V.; Rangappa, S.; Bharathkumar, H.; Kumar, A.P.; Lobie, P.E.; Rangappa, K.S. An azaspirane derivative suppresses growth and induces apoptosis of ER-positive and ER-negative breast cancer cells through the modulation of JAK2/STAT3 signaling pathway. Int. J. Oncol. 2016, 49, 1221-1229. [CrossRef] [PubMed]

15. Loh, C.-Y.; Arya, A.; Naema, A.F.; Wong, W.F.; Sethi, G.; Looi, C.Y. Signal Transducer and Activator of Transcription (STATs) Proteins in Cancer and Inflammation: Functions and Therapeutic Implication. Front. Oncol. 2019, 9. [CrossRef]

16. Lee, J.H.; Kim, C.; Lee, J.; Um, J.Y.; Sethi, G.; Ahn, K.S. Arctiin is a pharmacological inhibitor of STAT3 phosphorylation at tyrosine 705 residue and potentiates bortezomib-induced apoptotic and anti-angiogenic effects in human multiple myeloma cells. Phytomed. Int. J. Phytother. Phytopharmacol. 2019, 55, $282-292$. [CrossRef]

17. Lee, M.; Hirpara, J.L.; Eu, J.Q.; Sethi, G.; Wang, L.; Goh, B.C.; Wong, A.L. Targeting STAT3 and oxidative phosphorylation in oncogene-addicted tumors. Redox Biol. 2018, 101073. [CrossRef] 
18. Lee, J.H.; Kim, C.; Ko, J.H.; Jung, Y.Y.; Jung, S.H.; Kim, E.; Kong, M.; Chinnathambi, A.; Alahmadi, T.A.; Alharbi, S.A.; et al. Casticin inhibits growth and enhances ionizing radiation-induced apoptosis through the suppression of STAT3 signaling cascade. J. Cell. Biochem. 2019, 120, 9787-9798. [CrossRef]

19. Lee, J.H.; Kim, C.; Baek, S.H.; Ko, J.H.; Lee, S.G.; Yang, W.M.; Um, J.Y.; Sethi, G.; Ahn, K.S. Capsazepine inhibits JAK/STAT3 signaling, tumor growth, and cell survival in prostate cancer. Oncotarget 2017, 8, 17700-17711. [CrossRef]

20. Lee, J.H.; Kim, C.; Lee, S.-G.; Sethi, G.; Ahn, K.S. Ophiopogonin D, a Steroidal Glycoside Abrogates STAT3 Signaling Cascade and Exhibits Anti-Cancer Activity by Causing GSH/GSSG Imbalance in Lung Carcinoma. Cancers 2018, 10, 427. [CrossRef]

21. Siveen, K.S.; Sikka, S.; Surana, R.; Dai, X.; Zhang, J.; Kumar, A.P.; Tan, B.K.; Sethi, G.; Bishayee, A. Targeting the STAT3 signaling pathway in cancer: Role of synthetic and natural inhibitors. Biochim. Biophys. Acta 2014, 1845, 136-154. [CrossRef] [PubMed]

22. Wong, A.L.A.; Hirpara, J.L.; Pervaiz, S.; Eu, J.Q.; Sethi, G.; Goh, B.C. Do STAT3 inhibitors have potential in the future for cancer therapy? Expert Opin. Investig. Drugs 2017, 26, 883-887. [CrossRef] [PubMed]

23. Baek, S.H.; Ko, J.H.; Lee, H.; Jung, J.; Kong, M.; Lee, J.W.; Lee, J.; Chinnathambi, A.; Zayed, M.E.; Alharbi, S.A.; et al. Resveratrol inhibits STAT3 signaling pathway through the induction of SOCS-1: Role in apoptosis induction and radiosensitization in head and neck tumor cells. Phytomed. Int. J. Phytother. Phytopharmacol. 2016, 23, 566-577. [CrossRef] [PubMed]

24. Baek, S.H.; Lee, J.H.; Kim, C.; Ko, J.-H.; Ryu, S.-H.; Lee, S.-G.; Yang, W.M.; Um, J.-Y.; Chinnathambi, A.; Alharbi, S.A.; et al. Ginkgolic Acid C 17:1, Derived from Ginkgo biloba Leaves, Suppresses Constitutive and Inducible STAT3 Activation through Induction of PTEN and SHP-1 Tyrosine Phosphatase. Molecules 2017, 22, 276. [CrossRef]

25. Chai, E.Z.; Siveen, K.S.; Shanmugam, M.K.; Arfuso, F.; Sethi, G. Analysis of the intricate relationship between chronic inflammation and cancer. Biochem. J. 2015, 468, 1-15. [CrossRef]

26. Lee, J.H.; Kim, C.; Sethi, G.; Ahn, K.S. Brassinin inhibits STAT3 signaling pathway through modulation of PIAS-3 and SOCS-3 expression and sensitizes human lung cancer xenograft in nude mice to paclitaxel. Oncotarget 2015, 6, 6386-6405. [CrossRef]

27. Shanmugam, M.K.; Lee, J.H.; Chai, E.Z.; Kanchi, M.M.; Kar, S.; Arfuso, F.; Dharmarajan, A.; Kumar, A.P.; Ramar, P.S.; Looi, C.Y.; et al. Cancer prevention and therapy through the modulation of transcription factors by bioactive natural compounds. Semin. Cancer Biol. 2016, 40, 35-47. [CrossRef]

28. Zhang, J.; Ahn, K.S.; Kim, C.; Shanmugam, M.K.; Siveen, K.S.; Arfuso, F.; Samym, R.P.; Deivasigamanim, A.; Lim, L.H.; Wang, L.; et al. Nimbolide-Induced Oxidative Stress Abrogates STAT3 Signaling Cascade and Inhibits Tumor Growth in Transgenic Adenocarcinoma of Mouse Prostate Model. Antioxid. Redox Signal 2016, 24, 575-589. [CrossRef]

29. Rajendran, P.; Li, F.; Shanmugam, M.K.; Kannaiyan, R.; Goh, J.N.; Wong, K.F.; Wang, W.; Khin, E.; Tergaonkar, V.; Kumar, A.P.; et al. Celastrol suppresses growth and induces apoptosis of human hepatocellular carcinoma through the modulation of STAT3/JAK2 signaling cascade in vitro and in vivo. Cancer Prev. Res. 2012, 5, 631-643. [CrossRef]

30. Shanmugam, M.K.; Rajendran, P.; Li, F.; Kim, C.; Sikka, S.; Siveen, K.S.; Kumar, A.P.; Ahn, K.S.; Sethi, G. Abrogation of STAT3 signaling cascade by zerumbone inhibits proliferation and induces apoptosis in renal cell carcinoma xenograft mouse model. Mol. Carcinog. 2015, 54, 971-985. [CrossRef]

31. Mohan, C.D.; Bharathkumar, H.; Bulusu, K.C.; Pandey, V.; Rangappa, S.; Fuchs, J.E.; Shanmugam, M.K.; Dai, X.; Li, F.; Deivasigamani, A.; et al. Development of a novel azaspirane that targets the Janus kinase-signal transducer and activator of transcription (STAT) pathway in hepatocellular carcinoma in vitro and in vivo. J. Biol. Chem. 2014, 289, 34296-34307. [CrossRef] [PubMed]

32. Arora, L.; Kumar, A.P.; Arfuso, F.; Chng, W.J.; Sethi, G. The Role of Signal Transducer and Activator of Transcription 3 (STAT3) and Its Targeted Inhibition in Hematological Malignancies. Cancers 2018, 10, 327. [CrossRef] [PubMed]

33. Chai, E.Z.; Shanmugam, M.K.; Arfuso, F.; Dharmarajan, A.; Wang, C.; Kumar, A.P.; Samy, R.P.; Lim, L.H.; Wang, L.; Goh, B.C.; et al. Targeting transcription factor STAT3 for cancer prevention and therapy. Pharmacol. Ther. 2016, 162, 86-97. [CrossRef] [PubMed] 
34. Dai, X.; Ahn, K.S.; Kim, C.; Siveen, K.S.; Ong, T.H.; Shanmugam, M.K.; Li, F.; Shi, J.; Kumar, A.P.; Wang, L.Z.; et al. Ascochlorin, an isoprenoid antibiotic inhibits growth and invasion of hepatocellular carcinoma by targeting STAT3 signaling cascade through the induction of PIAS3. Mol. Oncol. 2015, 9, 818-833. [CrossRef] [PubMed]

35. Lee, J.H.; Kim, C.; Kim, S.H.; Sethi, G.; Ahn, K.S. Farnesol inhibits tumor growth and enhances the anticancer effects of bortezomib in multiple myeloma xenograft mouse model through the modulation of STAT3 signaling pathway. Cancer Lett. 2015, 360, 280-293. [CrossRef]

36. Keerthy, H.K.; Vivek, H.K.; Bharathkumar, H.; Rangappa, S.; Bulusu, K.C.; Mervin, L.H.; Fuchs, J.E.; Priya, B.S.; Basappa, B.; Swamy S, N.; et al. MOLPRINT 2D-based identification and synthesis of novel chromene based small molecules that target PLA2: Validation through chemo- and bioinformatics approaches. RSC Adv. 2015, 5, 89797-89808. [CrossRef]

37. Willett, P.; Barnard, J.M.; Downs, G.M. Chemical Similarity Searching. J. Chem. Inf. Comput. Sci. 1998, 38, 983-996. [CrossRef]

38. Bender, A.; Glen, R.C. Molecular similarity: A key technique in molecular informatics. Org. Biomol. Chem. 2004, 2, 3204-3218. [CrossRef]

39. Woo, C.C.; Hsu, A.; Kumar, A.P.; Sethi, G.; Tan, K.H. Thymoquinone inhibits tumor growth and induces apoptosis in a breast cancer xenograft mouse model: The role of p38 MAPK and ROS. PLoS ONE 2013, 8, e75356. [CrossRef]

40. Chua, A.W.; Hay, H.S.; Rajendran, P.; Shanmugam, M.K.; Li, F.; Bist, P.; Koay, E.S.; Lim, L.H.; Kumar, A.P.; Sethi, G. Butein downregulates chemokine receptor CXCR4 expression and function through suppression of NF-kappaB activation in breast and pancreatic tumor cells. Biochem. Pharmacol. 2010, 80, 1553-1562. [CrossRef]

41. Rakesh, K.S.; Jagadish, S.; Balaji, K.S.; Zameer, F.; Swaroop, T.R.; Mohan, C.D.; Jayarama, S.; Rangappa, K.S. 3,5-Disubstituted Isoxazole Derivatives: Potential Inhibitors of Inflammation and Cancer. Inflammation 2016, 39, 269-280. [CrossRef] [PubMed]

42. Sebastian, A.; Pandey, V.; Mohan, C.D.; Chia, Y.T.; Rangappa, S.; Mathai, J.; Baburajeev, C.P.; Paricharak, S.; Mervin, L.H.; Bulusu, K.C.; et al. Novel Adamantanyl-Based Thiadiazolyl Pyrazoles Targeting EGFR in Triple-Negative Breast Cancer. ACS Omega 2016, 1, 1412-1424. [CrossRef] [PubMed]

43. Baburajeev, C.P.; Mohan, C.D.; Rangappa, S.; Mason, D.J.; Fuchs, J.E.; Bender, A.; Barash, U.; Vlodavsky, I.; Basappa, B.; Rangappa, K.S. Identification of Novel Class of Triazolo-Thiadiazoles as Potent Inhibitors of Human Heparanase and their Anticancer Activity. BMC Cancer 2017, 17, 235. [CrossRef] [PubMed]

44. Gilandoust, M.; Harsha, K.B.; Mohan, C.D.; Raquib, A.R.; Rangappa, S.; Pandey, V.; Lobie, P.E.; Basappa, B.; Rangappa, K.S. Synthesis, characterization and cytotoxicity studies of 1,2,3-triazoles and 1,2,4-triazolo [1,5-a] pyrimidines in human breast cancer cells. Bioorg. Med. Chem. Lett. 2018, 28, 2314-2319. [CrossRef] [PubMed]

45. Mohan, C.D.; Bharathkumar, H.; Dukanya; Rangappa, S.; Shanmugam, M.K.; Chinnathambi, A.; Alharbi, S.A.; Alahmadi, T.A.; Bhattacharjee, A.; Lobie, P.E.; et al. N-Substituted Pyrido-1,4-Oxazin-3-Ones Induce Apoptosis of Hepatocellular Carcinoma Cells by Targeting NF-kappaB Signaling Pathway. Front. Pharmacol. 2018, 9, 1125. [CrossRef]

46. Pandey, V.; Wang, B.; Mohan, C.D.; Raquib, A.R.; Rangappa, S.; Srinivasa, V.; Fuchs, J.E.; Girish, K.S.; Zhu, T.; Bender, A.; et al. Discovery of a small-molecule inhibitor of specific serine residue BAD phosphorylation. Proc. Natl. Acad. Sci. USA 2018, 115, E10505-E10514. [CrossRef]

47. Jung, Y.Y.; Lee, J.H.; Nam, D.; Narula, A.S.; Namjoshi, O.A.; Blough, B.E.; Um, J.Y.; Sethi, G.; Ahn, K.S. Anti-myeloma Effects of Icariin Are Mediated Through the Attenuation of JAK/STAT3-Dependent Signaling Cascade. Front. Pharmacol. 2018, 9, 531. [CrossRef]

48. Kim, C.; Lee, S.G.; Yang, W.M.; Arfuso, F.; Um, J.Y.; Kumar, A.P.; Bian, J.; Sethi, G.; Ahn, K.S. Formononetin-induced oxidative stress abrogates the activation of STAT3/5 signaling axis and suppresses the tumor growth in multiple myeloma preclinical model. Cancer Lett. 2018, 431, 123-141. [CrossRef]

49. Ko, H.; Lee, J.H.; Kim, H.S.; Kim, T.; Han, Y.T.; Suh, Y.G.; Chun, J.; Kim, Y.S. Novel Galiellalactone Analogues Can Target STAT3 Phosphorylation and Cause Apoptosis in Triple-Negative Breast Cancer. Biomolecules 2019, 9, 170. [CrossRef]

50. Mohan, C.D.; Anilkumar, N.C.; Rangappa, S.; Shanmugam, M.K.; Mishra, S.; Chinnathambi, A.; Alharbi, S.A.; Bhattacharjee, A.; Sethi, G.; Kumar, A.P.; et al. Novel 1,3,4-Oxadiazole Induces Anticancer Activity by Targeting NF-kappaB in Hepatocellular Carcinoma Cells. Front. Oncol. 2018, 8, 42. [CrossRef] 
51. Subramanian, G.; Babu Rajeev, C.P.; Mohan, C.D.; Sinha, A.; Chu, T.T.T.; Anusha, S.; Ximei, H.; Fuchs, J.E.; Bender, A.; Rangappa, K.S.; et al. Synthesis and in vitro evaluation of hydrazinyl phthalazines against malaria parasite, Plasmodium falciparum. Bioorg. Med. Chem. Lett. 2016, 26, 3300-3306. [CrossRef] [PubMed]

52. Srinivas, V.; Mohan, C.D.; Baburajeev, C.P.; Rangappa, S.; Jagadish, S.; Fuchs, J.E.; Sukhorukov, A.Y.; Chandra; Mason, D.J.; Sharath Kumar, K.S.; et al. Synthesis and characterization of novel oxazines and demonstration that they specifically target cyclooxygenase 2. Bioorg. Med. Chem. Lett. 2015, 25, 2931-2936. [CrossRef] [PubMed]

53. Becker, S.; Groner, B.; Muller, C.W. Three-dimensional structure of the Stat3beta homodimer bound to DNA. Nature 1998, 394, 145-151. [CrossRef] [PubMed]

54. Anusha, S.; Mohan, C.D.; Ananda, H.; Baburajeev, C.P.; Rangappa, S.; Mathai, J.; Fuchs, J.E.; Li, F.; Shanmugam, M.K.; Bender, A.; et al. Adamantyl-tethered-biphenylic compounds induce apoptosis in cancer cells by targeting Bcl homologs. Bioorg. Med. Chem. Lett. 2016, 26, 1056-1060. [CrossRef] [PubMed]

55. Irwin, J.J.; Sterling, T.; Mysinger, M.M.; Bolstad, E.S.; Coleman, R.G. ZINC: A free tool to discover chemistry for biology. J. Chem. Inf. Model. 2012, 52, 1757-1768. [CrossRef] [PubMed]

56. Sethi, G.; Chatterjee, S.; Rajendran, P.; Li, F.; Shanmugam, M.K.; Wong, K.F.; Kumar, A.P.; Senapati, P.; Behera, A.K.; Hui, K.M.; et al. Inhibition of STAT3 dimerization and acetylation by garcinol suppresses the growth of human hepatocellular carcinoma in vitro and in vivo. Mol. Cancer 2014, 13, 66. [CrossRef]

57. Kim, S.M.; Lee, J.H.; Sethi, G.; Kim, C.; Baek, S.H.; Nam, D.; Chung, W.S.; Kim, S.H.; Shim, B.S.; Ahn, K.S. Bergamottin, a natural furanocoumarin obtained from grapefruit juice induces chemosensitization and apoptosis through the inhibition of STAT3 signaling pathway in tumor cells. Cancer Lett. 2014, 354, 153-163. [CrossRef]

58. Subramaniam, A.; Shanmugam, M.K.; Ong, T.H.; Li, F.; Perumal, E.; Chen, L.; Vali, S.; Abbasi, T.; Kapoor, S.; Ahn, K.S.; et al. Emodin inhibits growth and induces apoptosis in an orthotopic hepatocellular carcinoma model by blocking activation of STAT3. Br. J. Pharmacol. 2013, 170, 807-821. [CrossRef]

59. Subramaniam, A.; Shanmugam, M.K.; Perumal, E.; Li, F.; Nachiyappan, A.; Dai, X.; Swamy, S.N.; Ahn, K.S.; Kumar, A.P.; Tan, B.K.; et al. Potential role of signal transducer and activator of transcription (STAT) 3 signaling pathway in inflammation, survival, proliferation and invasion of hepatocellular carcinoma. Biochim. Biophys. 2013, 1835, 46-60. [CrossRef]

60. Li, F.; Rajendran, P.; Sethi, G. Thymoquinone inhibits proliferation, induces apoptosis and chemosensitizes human multiple myeloma cells through suppression of signal transducer and activator of transcription 3 activation pathway. Br. J. Pharmacol. 2010, 161, 541-554. [CrossRef]

61. Kannaiyan, R.; Hay, H.S.; Rajendran, P.; Li, F.; Shanmugam, M.K.; Vali, S.; Abbasi, T.; Kapoor, S.; Sharma, A.; Kumar, A.P.; et al. Celastrol inhibits proliferation and induces chemosensitization through down-regulation of NF-kappaB and STAT3 regulated gene products in multiple myeloma cells. Br. J. Pharmacol. 2011, 164, 1506-1521. [CrossRef] [PubMed]

62. Rajendran, P.; Li, F.; Manu, K.A.; Shanmugam, M.K.; Loo, S.Y.; Kumar, A.P.; Sethi, G. gamma-Tocotrienol is a novel inhibitor of constitutive and inducible STAT3 signalling pathway in human hepatocellular carcinoma: Potential role as an antiproliferative, pro-apoptotic and chemosensitizing agent. Br. J. Pharmacol. 2011, 163, 283-298. [CrossRef] [PubMed]

63. Rajendran, P.; Li, F.; Shanmugam, M.K.; Vali, S.; Abbasi, T.; Kapoor, S.; Ahn, K.S.; Kumar, A.P.; Sethi, G. Honokiol inhibits signal transducer and activator of transcription-3 signaling, proliferation, and survival of hepatocellular carcinoma cells via the protein tyrosine phosphatase SHP-1. J. Cell. Phys. 2012, 227, 2184-2195. [CrossRef] [PubMed]

64. Murata, T.; Shimada, M.; Sakakibara, S.; Yoshino, T.; Kadono, H.; Masuda, T.; Shimazaki, M.; Shintani, T.; Fuchikami, K.; Sakai, K.; et al. Discovery of novel and selective IKK-beta serine-threonine protein kinase inhibitors. Part 1. Bioorg. Med. Chem. Lett. 2003, 13, 913-918. [CrossRef]

65. Sanda, T.; Iida, S.; Ogura, H.; Asamitsu, K.; Murata, T.; Bacon, K.B.; Ueda, R.; Okamoto, T. Growth inhibition of multiple myeloma cells by a novel IкB kinase inhibitor. Clin. Cancer Res. 2005, 11, 1974-1982. [CrossRef] [PubMed]

66. Murata, T.; Shimada, M.; Sakakibara, S.; Yoshino, T.; Masuda, T.; Shintani, T.; Sato, H.; Koriyama, Y.; Fukushima, K.; Nunami, N.; et al. Synthesis and structure-activity relationships of novel IKK-beta inhibitors. Part 3: Orally active anti-inflammatory agents. Bioorg. Med. Chem. Lett. 2004, 14, 4019-4022. [CrossRef] 
67. Sanda, T.; Asamitsu, K.; Ogura, H.; Iida, S.; Utsunomiya, A.; Ueda, R.; Okamoto, T. Induction of cell death in adult T-cell leukemia cells by a novel IкB kinase inhibitor. Leukemia 2006, 20, 590-598. [CrossRef]

68. Puar, Y.R.; Shanmugam, M.K.; Fan, L.; Arfuso, F.; Sethi, G.; Tergaonkar, V. Evidence for the Involvement of the Master Transcription Factor NF-kappaB in Cancer Initiation and Progression. Biomedicines 2018, 6, 82. [CrossRef]

69. Shin, E.M.; Hay, H.S.; Lee, M.H.; Goh, J.N.; Tan, T.Z.; Sen, Y.P.; Lim, S.W.; Yousef, E.M.; Ong, H.T.; Thike, A.A.; et al. DEAD-box helicase DP103 defines metastatic potential of human breast cancers. J. Clin. Investig. 2014, 124, 3807-3824. [CrossRef]

70. Ahn, K.S.; Sethi, G.; Aggarwal, B.B. Reversal of chemoresistance and enhancement of apoptosis by statins through down-regulation of the NF-kappaB pathway. Biochem. Pharmacol. 2008, 75, 907-913. [CrossRef]

71. Ahn, K.S.; Sethi, G.; Chaturvedi, M.M.; Aggarwal, B.B. Simvastatin, 3-hydroxy-3-methylglutaryl coenzyme A reductase inhibitor, suppresses osteoclastogenesis induced by receptor activator of nuclear factor-kappaB ligand through modulation of NF-kappaB pathway. Int. J. Cancer 2008, 123, 1733-1740. [CrossRef] [PubMed]

72. Manna, S.K.; Aggarwal, R.S.; Sethi, G.; Aggarwal, B.B.; Ramesh, G.T. Morin (3,5,7,2' '4' -Pentahydroxyflavone) abolishes nuclear factor-kappaB activation induced by various carcinogens and inflammatory stimuli, leading to suppression of nuclear factor-kappaB-regulated gene expression and up-regulation of apoptosis. Clin. Cancer Res. Off. J. Am. Assoc. Cancer Res. 2007, 13, 2290-2297. [CrossRef] [PubMed]

73. Mia, M.M.; Bank, R.A. The IкB kinase inhibitor ACHP strongly attenuates TGF $\beta 1$-induced myofibroblast formation and collagen synthesis. J. Cell. Mol. Med. 2015, 19, 2780-2792. [CrossRef] [PubMed]

74. Li, L.; Cataisson, C.; Flowers, B.; Fraser, E.; Sanchez, V.; Day, C.-P.; Yuspa, S.H. Topical Application of a Dual ABC Transporter Substrate and NF- $\mathrm{kB}$ Inhibitor Blocks Multiple Sources of Cutaneous Inflammation in Mouse Skin. J. Investig. Dermatol. 2019. [CrossRef] [PubMed]

75. Neelgundmath, M.; Dinesh, K.R.; Mohan, C.D.; Li, F.; Dai, X.; Siveen, K.S.; Paricharak, S.; Mason, D.J.; Fuchs, J.E.; Sethi, G.; et al. Novel synthetic coumarins that targets NF-kB in Hepatocellular carcinoma. Bioorg. Med. Chem. Lett. 2015, 25, 893-897. [CrossRef] [PubMed]

76. Keerthy, H.K.; Mohan, C.D.; Sivaraman Siveen, K.; Fuchs, J.E.; Rangappa, S.; Sundaram, M.S.; Li, F.; Girish, K.S.; Sethi, G.; Basappa, B.; et al. Novel synthetic biscoumarins target tumor necrosis factor-alpha in hepatocellular carcinoma in vitro and in vivo. J. Biol. Chem. 2014, 289, 31879-31890. [CrossRef] [PubMed]

77. Nan, J.; Du, Y.; Chen, X.; Bai, Q.; Wang, Y.; Zhang, X.; Zhu, N.; Zhang, J.; Hou, J.; Wang, Q.; et al. TPCA-1 is a direct dual inhibitor of STAT3 and NF-kappaB and regresses mutant EGFR-associated human non-small cell lung cancers. Mol. Cancer Ther. 2014, 13, 617-629. [CrossRef] [PubMed]

78. McFarland, B.C.; Gray, G.K.; Nozell, S.E.; Hong, S.W.; Benveniste, E.N. Activation of the NF-кB pathway by the STAT3 inhibitor JSI-124 in human glioblastoma cells. Mol. Cancer Res. 2013, 11, 494-505. [CrossRef]

79. Nair, A.S.; Shishodia, S.; Ahn, K.S.; Kunnumakkara, A.B.; Sethi, G.; Aggarwal, B.B. Deguelin, an Akt inhibitor, suppresses IkappaBalpha kinase activation leading to suppression of NF-kappaB-regulated gene expression, potentiation of apoptosis, and inhibition of cellular invasion. J. Immunol. 2006, 177, 5612-5622. [CrossRef]

80. Podolin, P.L.; Callahan, J.F.; Bolognese, B.J.; Li, Y.H.; Carlson, K.; Davis, T.G.; Mellor, G.W.; Evans, C.; Roshak, A.K. Attenuation of murine collagen-induced arthritis by a novel, potent, selective small molecule inhibitor of IkappaB Kinase 2, TPCA-1 (2-[(aminocarbonyl)amino]-5-(4-fluorophenyl)-3-thiophenecarboxamide), occurs via reduction of proinflammatory cytokines and antigen-induced T cell Proliferation. J. Pharmacolo. Exp. Ther. 2005, 312, 373-381. [CrossRef]

81. Harada, D.; Takigawa, N.; Kiura, K. The Role of STAT3 in Non-Small Cell Lung Cancer. Cancers 2014, 6, 708-722. [CrossRef] [PubMed]

82. Yin, Z.J.; Jin, F.G.; Liu, T.G.; Fu, E.Q.; Xie, Y.H.; Sun, R.L. Overexpression of STAT3 potentiates growth, survival, and radioresistance of non-small-cell lung cancer (NSCLC) cells. J. Surg. Res. 2011, 171, 675-683. [CrossRef] [PubMed]

83. Bonner, J.A.; Trummell, H.Q.; Willey, C.D.; Plants, B.A.; Raisch, K.P. Inhibition of STAT-3 results in radiosensitization of human squamous cell carcinoma. Radiother. Oncol. 2009, 92, 339-344. [CrossRef] [PubMed]

84. Lee, J.H.; Rangappa, S.; Mohan, C.D.; Basappa, B.; Sethi, G.; Lin, Z.-X.; Rangappa, K.S.; Ahn, K.S. Brusatol, a Nrf2 Inhibitor Targets STAT3 Signaling Cascade in Head and Neck Squamous Cell Carcinoma. Biomolecules 2019, 9, 550. [CrossRef] 
85. Yin, Z.; Zhang, Y.; Li, Y.; Lv, T.; Liu, J.; Wang, X. Prognostic significance of STAT3 expression and its correlation with chemoresistance of non-small cell lung cancer cells. Acta Histochem. 2012, 114, 151-158. [CrossRef]

86. Demaria, M.; Misale, S.; Giorgi, C.; Miano, V.; Camporeale, A.; Campisi, J.; Pinton, P.; Poli, V. STAT3 can serve as a hit in the process of malignant transformation of primary cells. Cell Death Differ. 2012, 19, 1390-1397. [CrossRef]

87. Zhang, H.-F.; Lai, R. STAT3 in Cancer-Friend or Foe? Cancers 2014, 6, 1408-1440. [CrossRef]

88. Baburajeev, C.P.; Mohan, C.D.; Patil, G.S.; Rangappa, S.; Pandey, V.; Sebastian, A.; Fuchs, J.E.; Bender, A.; Lobie, P.E.; Basappa, B.; et al. Nano-cuprous oxide catalyzed one-pot synthesis of a carbazole-based STAT3 inhibitor: A facile approach via intramolecular C-N bond formation reactions. RSC Adv. 2016, 6, 36775-36785. [CrossRef]

89. Shah, M.; Patel, K.; Mukhopadhyay, S.; Xu, F.; Guo, G.; Sehgal, P.B. Membrane-associated STAT3 and PY-STAT3 in the cytoplasm. J. Biol. Chem. 2006, 281, 7302-7308. [CrossRef]

90. Tan, S.M.; Li, F.; Rajendran, P.; Kumar, A.P.; Hui, K.M.; Sethi, G. Identification of beta-escin as a novel inhibitor of signal transducer and activator of transcription 3/Janus-activated kinase 2 signaling pathway that suppresses proliferation and induces apoptosis in human hepatocellular carcinoma cells. J. Pharmacol. Exp. Ther. 2010, 334, 285-293. [CrossRef]

91. Nirvanappa, A.C.; Mohan, C.D.; Rangappa, S.; Ananda, H.; Sukhorukov, A.Y.; Shanmugam, M.K.; Sundaram, M.S.; Nayaka, S.C.; Girish, K.S.; Chinnathambi, A.; et al. Novel Synthetic Oxazines Target NF-kappaB in Colon Cancer In Vitro and Inflammatory Bowel Disease In Vivo. PLoS ONE 2016, 11, e0163209. [CrossRef] [PubMed]

92. Baburajeev, C.; Mohan, C.D.; Ananda, H.; Rangappa, S.; Fuchs, J.E.; Jagadish, S.; Siveen, K.S.; Chinnathambi, A.; Alharbi, S.A.; Zayed, M. Development of novel triazolo-thiadiazoles from heterogeneous "green" catalysis as protein tyrosine phosphatase 1B inhibitors. Sci. Rep. 2015, 5, 14195. [CrossRef] [PubMed]

93. Niu, G.; Wright, K.L.; Ma, Y.; Wright, G.M.; Huang, M.; Irby, R.; Briggs, J.; Karras, J.; Cress, W.D.; Pardoll, D. Role of Stat3 in regulating p53 expression and function. Mol. Cell. Biol. 2005, 25, 7432-7440. [CrossRef] [PubMed]

94. Niu, G.; Shain, K.H.; Huang, M.; Ravi, R.; Bedi, A.; Dalton, W.S.; Jove, R.; Yu, H. Overexpression of a dominant-negative signal transducer and activator of transcription 3 variant in tumor cells leads to production of solublefactors that induce apoptosis and cell cycle arrest. Cancer Res. 2001, 61, 3276-3280. [PubMed]

95. Zhang, Q.; Wang, H.Y.; Marzec, M.; Raghunath, P.N.; Nagasawa, T.; Wasik, M.A. STAT3-and DNA methyltransferase 1-mediated epigenetic silencing of SHP-1 tyrosine phosphatase tumor suppressor gene in malignant T lymphocytes. Proc. Natl. Acad. Sci. USA 2005, 102, 6948-6953. [CrossRef] [PubMed]

96. De la Iglesia, N.; Konopka, G.; Puram, S.V.; Chan, J.A.; Bachoo, R.M.; You, M.J.; Levy, D.E.; Depinho, R.A.; Bonni, A. Identification of a PTEN-regulated STAT3 brain tumor suppressor pathway. Genes Dev. 2008, 22, 449-462. [CrossRef] [PubMed]

97. Schneller, D.; Machat, G.; Sousek, A.; Proell, V.; van Zijl, F.; Zulehner, G.; Huber, H.; Mair, M.; Muellner, M.K.; Nijman, S.M.; et al. p19(ARF)/p14(ARF) controls oncogenic functions of signal transducer and activator of transcription 3 in hepatocellular carcinoma. Hepatology 2011, 54, 164-172. [CrossRef]

98. Caetano, M.S.; Hassane, M.; Van, H.T.; Bugarin, E.; Cumpian, A.M.; McDowell, C.L.; Cavazos, C.G.; Zhang, H.; Deng, S.; Diao, L.; et al. Sex specific function of epithelial STAT3 signaling in pathogenesis of K-ras mutant lung cancer. Nat. Commun. 2018, 9, 4589. [CrossRef]

(C) 2019 by the authors. Licensee MDPI, Basel, Switzerland. This article is an open access article distributed under the terms and conditions of the Creative Commons Attribution (CC BY) license (http://creativecommons.org/licenses/by/4.0/). 